Note

\title{
PRODUCTION OF STREPTOMYCETE INOCULUM IN STERILIZED RICE
}

\author{
Ana Cristina Fermino Soares ${ }^{1 *}$; Carla da Silva Sousa²; Marlon da Silva Garrido²; Jane Oliveira \\ Perez $^{1}$ \\ ${ }_{2}^{1}$ UFRB - Centro de Ciências Agrárias, Ambientais e Biológicas - 44380-000 - Cruz das Almas, BA - Brasil. \\ ${ }^{2}$ UFRB - Programa de Pós-Graduação em Ciências Agrárias. \\ *Corresponding author <acsoares@ufrb.edu.br>
}

\begin{abstract}
Actinomycetes are important plant disease control and growth promotion agents, which makes it necessary to develop technology to produce large quantities of inoculum for green-house and field work. The present study had the objective of evaluating the growth of several isolates of Streptomyces in sterile rice for inoculum production. The sterile rice was inoculated with isolates of $S$. thermotolerans, S. griseus subsp. griseus, Streptomyces sp. N0035, S. purpurascens, and Streptomyces sp., and incubated at $28 \pm 2^{\circ} \mathrm{C}$. Five days after its inoculation, mycelial growth and sporulation was observed for all Streptomyces isolates on the rice grains. Twelve days after incubation, the colonized rice was transferred to envelopes of dark brown paper and let to dry in an incubator at $30^{\circ} \mathrm{C}$ for three days. After drying, $1 \mathrm{~g}$ of colonized rice was added to $200 \mathrm{~mL}$ of sterile distilled water and the number of spores was counted under a microscope with a Newbauer counting chamber. Spore production varied from $0.14 \times 10^{9}$ to $1.47 \times 10^{9}$ spores per gram of rice and differed among the Streptomyces species. Sterile rice can be an alternative substrate for low cost mass production of Streptomyces inoculum.
\end{abstract}

Key words: actinomycetes, biological control, growth substrates

\section{PRODUÇÃO DE INÓCULO DE ESTREPTOMICETO EMARROZ ESTERILIZADO}

\begin{abstract}
RESUMO: Os actinomicetos são importantes agentes de controle biológico de doenças e promoção de crescimento de plantas, tornando necessária a obtenção de grandes quantidades de inóculo para trabalhos em casa-de-vegetação e campo. No presente trabalho, avaliou-se o crescimento de diversas espécies de Streptomyces em arroz esterilizado para a produção de inoculo. O arroz foi inoculado com isolados de S. thermotolerans, S. griseus subsp. griseus, Streptomyces sp. N0035, S. purpurascens e Streptomyces sp. e incubado a $28 \pm 2^{\circ} \mathrm{C}$. Cinco dias após a incubação, para todos os isolados de Streptomyces, o crescimento micelial e esporulação eram visíveis nos grãos de arroz. Doze dias após incubação, o arroz colonizado foi transferido para envelopes de papel pardo e colocado em estufa a $30^{\circ} \mathrm{C}$ por três dias. Após secagem, adicionou-se $1 \mathrm{~g}$ do arroz em $200 \mathrm{~mL}$ de água e fez-se a contagem de esporos por grama de arroz, em câmara de Newbauer. A produção de esporos de Streptomyces $s p$. variou de $0,14 \times 10^{9}$ a $1,47 \times 10^{9}$ esporos por grama de arroz e variou entre as espécies de Streptomyces. O arroz esterilizado é um substrato viável para a produção massal, de baixo custo, de inóculo de estreptomicetos.

Palavras-chave: actinomicetos, controle biológico, substratos para crescimento
\end{abstract}

\section{INTRODUCTION}

Actinomycetes have important characteristics for biological control and plant growth promoting agents, due to their capacity to produce spores, antibiotics, enzymes with antimicrobial activity, plant growth promoting substances and to act as organic matter decomposers (Crawford et al., 1993). These microorganisms have an important role in the degra- dation of polymers such as lignin, chitin, cellulose, and starch (Crawford, 1988; Nolan \& Cross, 1988), the control of plant pathogens (Getha et al., 2005; Minuto et al., 2006; Sousa et al., 2006), as well as in the production of other important secondary metabolites of industrial interest (Lancini \& Lorenzetti, 1993).

To use these plant biocontrol and growth promotion agents, either in green-house or field conditions, it is necessary to produce large amounts of in- 
oculum. For such studies, strains of actinomycetes grown in culture media are usually resuspended in sterile water or buffered solutions for the suspensions be used as inoculum (Cao et al., 2005). A Streptomyces sp. delivery medium consisting of $5 \%(\mathrm{w} / \mathrm{w})$ sago hampas in soil, autoclaved and adjusted to moisture content of $40 \%$, was described by Stevenson (1956) and used by Getha et al. (2005). Actinomycete inoculum production in sterile moist wheat bran as the growth substrate and its use for soil inoculation has also been described (El-Tarabily et al., 2000). In addition, some studies have used commercial biocontrol agents in powder formulations such as Mycostop ${ }^{\circledR}$ (Verdera OY, Helsinki, Finland), a formulation with $S$. griseoviridis, for the control of soilborn tomato pathogens (Minuto et al., 2006).

For fungi, a classical example is the large scale production of Beauveria and Metarhizium in rice grains for biological control of insects (Nelson et al., 1996) and large scale production of Trichoderma species in rice grains for biological control of plant pathogenic fungi. The development of technology for mass production of biocontrol agents can involve large companies with large capital investments in automated processes for large-scale production of commercial powder formulations, or more labour-intensive small scale production models which are economically viable for small scale market supply (Jenkins et al., 1998).

The present study had the objective of evaluating the growth of different species of Streptomyces in sterile rice grains for inoculum mass production.

\section{MATERIAL AND METHODS}

To hydrate the rice grains, $500 \mathrm{~mL}$ of distilled water was added to $300 \mathrm{~g}$ of rice and kept at room temperature for one hour. The excess of water was removed by using a 35 mesh sieve and aliquots of 50 $\mathrm{g}$ of rice were transferred to glass pots, which were covered with aluminum foil and sealed with plastic wrap film to prevent evaporation. The rice in the glass pots was sterilized in the autoclave at $120^{\circ} \mathrm{C}$, for 55 minutes.

To inoculate the sterile rice, the Streptomyces isolates were grown in arginine-glycerol-mineral salt agar media (Poter et al., 1960) in Petri dishes and incubated for ten days in a growth chamber at $28 \pm$ $2^{\circ} \mathrm{C}$. The isolates tested were Streptomyces sp., $S$. thermotolerans, S. griseus subsp. griseus, Streptomyces sp. N0035, and S. purpurascens, which had been selected in previous work as potential biocontrol agents (Lima, 2003; Soares et al., 2006; Sousa et al., 2006). The cell suspension of each Streptomyces isolate was prepared by adding $15 \mathrm{~mL}$ of sterile distilled water to each Petri dish and the Streptomyces colonies were scraped with a bacterial loop. The suspension's cell concentration was adjusted with sterile water to absorbance of $\mathrm{A}_{540}=0.3$ in a UV spectrophotometer. One mililiter of the Streptomyces cell suspension was added to each $50 \mathrm{~g}$ rice aliquot. Six replicates were made for each isolate tested. The inoculated rice pots were covered with aluminum foil, sealed with plastic wrap film and incubated at $28 \pm$ $2^{\circ} \mathrm{C}$.

After 12 days of incubation, the colonized rice (Figure 1) was transferred to brown paper envelopes and dried in an oven at $30^{\circ} \mathrm{C}$, for three days, in order to facilitate spore extraction from the rice grains. After the drying period, $1 \mathrm{~g}$ of rice was added to 200 $\mathrm{mL}$ of sterile distilled water, the mixture was hand shaken and the suspension was filtered through a piece of cheese cloth. The number of spores in the filtered suspension was quantified by counting under a light microscope with a Newbauer chamber. For all tested Streptomyces species, colonized rice grains were inoculated onto arginine-glycerol-mineral salt agar plates and incubated at $28 \pm 2^{\circ} \mathrm{C}$ to check for inoculums viability.

The experimental design was a completely randomized block with six replicates. The analysis of variance (ANOVA) and the comparison of means by the Tukey test were performed with the statistical SISVAR (Ferreira, 2000).

\section{RESULTS AND DISCUSSION}

Mycelial growth and sporulation of the Streptomyces species were visually perceptible on the rice grains five days after inoculation. Spore production varied from $0.14 \times 10^{9}$ to $1.47 \times 10^{9}$ spores $\mathrm{g}^{-1}$ of rice, after incubation for 12 days at $28^{\circ} \mathrm{C}$, followed by drying at $30^{\circ} \mathrm{C}$ for 3 days (Table 1 ). Streptomyces sp. presented the highest number of spore production per gram of colonized rice, in relation to the other isolates, while Streptomyces sp. N0035 presented the lowest spore production per gram of colonized rice (Table 1).

Table 1 - Quantification of spores per gram of rice grains colonized by Streptomycete isolates.

\begin{tabular}{lc}
\hline Streptomycete isolates & $\mathrm{N}^{0}$ of spores $\mathrm{g}^{-1}$ of rice* \\
\hline Streptomyces sp. & $1.42 \times 10^{9} \mathrm{a}$ \\
S. thermotolerans & $0.54 \times 10^{9} \mathrm{ab}$ \\
S. griseus subsp. griseus & $1.10 \times 10^{9} \mathrm{ab}$ \\
Streptomyces sp. N0035 & $0.08 \times 10^{9} \mathrm{~b}$ \\
S. purpurascens & $0.33 \times 10^{9} \mathrm{ab}$ \\
\hline
\end{tabular}

*Means followed by the same letter do not differ by the test of Tukey at $(P<0.05)$. 

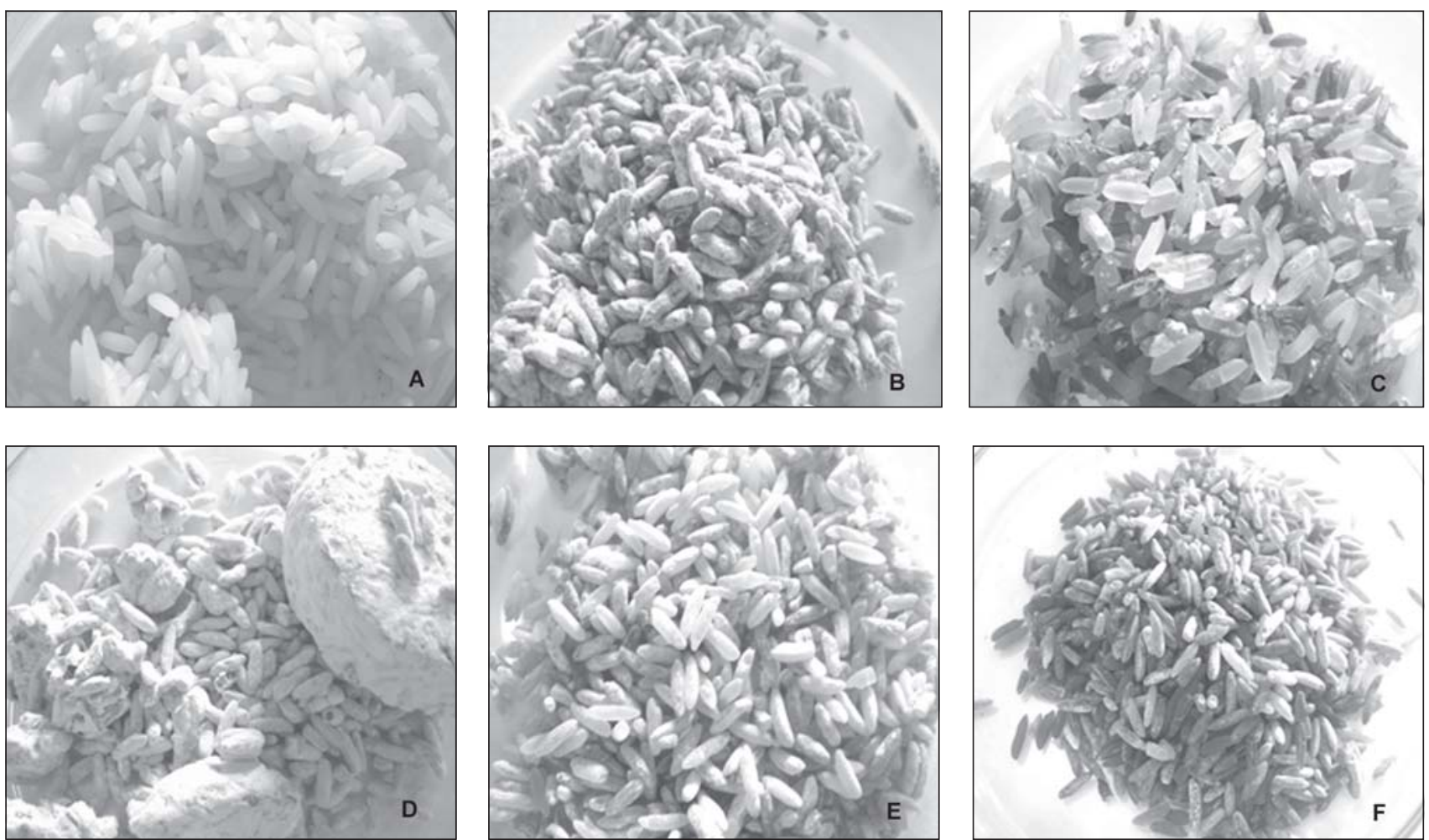

Figure 1 - Sterilized rice (A) and rice colonized by Streptomyces thermotolerans (B), Streptomyces purpurascens (C), Streptomyces griseus subsp. griseus (D), Streptomyces sp. (E), and Streptomyces sp. N0035 (F).

Although S. griseus subsp. griseus and Streptomyces sp. N0035 appeared to have higher levels of rice colonization (Figure 1), these were not the isolates with the highest production of spores (Table 1), possibly due to the growth of a large quantity of nondifferentiated mycelia. However, a microscopic study of rice grains colonized by these actinomycetes for observation of substrate and aerial hyphae with spore chains was not performed.

The viability of the rice inoculum was confirmed by the growth of all Streptomyces species from colonized rice grains on arginine-glycerol-mineral salt agar plates at $28 \pm 2^{\circ} \mathrm{C}$ and in vitro antagonism to some plant fungal pathogens (data not shown). However, the percentage of spore germination, as described by Hirsch \& Ensign (1976), was not determined for the rice based Streptomyces spore inoculum. Spore germinability may also vary with the Streptomyces species and growth conditions (Hirsch \& Ensign, 1976). On the other hand, rice grains colonized by these Streptomycete isolates have been used for inoculation of a commercial planting mix, for evaluating their potential for controlling Meloidogyne incognita in tomato seedlings (Sousa et al., 2006). These authors demonstrated that Streptomyces sp. N0035, S. purpurascens and S. griseus subspecies griseus rice inoculum caused significant reduction in the number of root galls and egg masses in tomato plants inoculated with $M$. incognita. Growth promotion was also observed in tomato plants grown in pots with planting mix inoculated with Streptomyces rice inoculum (Sousa, 2006; Sousa et al., 2006). In addition, these Streptomyces species have been indicated as potential biological agents for controlling yam (Dioscorea cayennensis Lam.) phytophathogenic fungi associated with leaf spot diseases (Soares et al., 2006).

Records of Streptomyces inoculum production in rice grains were not found in the consulted literature. The growth of Streptomyces species in sterile moistened rice grains can be a viable method for mass production of inoculum. Yet, the inoculum concentration, in regard to spore production, varied with the Streptomyces species.

Growth of actinomycetes and production of secondary metabolites varies with the isolate, growth conditions, such as carbon and nitrogen sources, as well as $\mathrm{pH}$, oxygen level and temperature conditions (El-Enshasy et al., 2000). In addition, the type of inoculum (spores and vegetative cells) also affects the production of secondary metabolites (El-Enshasy et al., 2000). Therefore, for each Streptomyces species or isolate, the ability to produce high-titre inocula should be tested with a variety of substrates and growth conditions. 


\section{ACKNOWLEDGMENTS}

To FAPESB, for the project financial support and the PRODOC assistantship. To CAPES for M.Sc. assistantship. To Dr. Ricardo Harakava, from the Instituto Biológico, Laboratory of Biochemistry and Phytopathology, São Paulo, Brazil, for DNA sequencing of the Streptomycete isolates, and Dr. Kazunori Hatano, form the Department of Biotechnology of the National Institute of Technology and Evaluation (NITE), in Japan, for the molecular identification of the Streptomycete isolates.

\section{REFERENCES}

CAO, L.; QIU, Z.; YOU, J.; TAN, H.; ZHOU, S. Isolation and characterization of endophytic streptomycete antagonists of Fusarium wilt pathogen from surface-sterilized banana roots. FEMS Microbiology Letters, v.247, p.147-152, 2005.

CRAWFORD, D. L. Biodegradation of agricultural and urban wastes. In: GOODFELLOW, M.; WILLIAMS, S.T.; MORDARSKI, M. (Ed.). Actinomycetes in biotechnology. San Diego: Wiley Interscience, 1988. p.433-459.

CRAWFORD, D.L.; LYNCH, J.M.; WHIPPS, J.M.; OUSLEY, M.A. Isolation and characterization of actinomycete antagonist of fungal root pathogen. Applied and Environmental Microbiology, v.59, p.3899-3905, 1993.

EL-ENSHASY, H.A.; FARID, M.A.; EL-SAYED, E.A. Influence of inoculums type and cultivation conditions on natamycin production by Streptomyces natalensis. Journal of Basic Microbiology, v.40, p.333-342, 2000.

EL-TARABILY, K.A.; SOLIMAN, M.H.; NASSAR, A.H.; ALHASSANI, H.A.; SIVASITHAMPARAM, K.; MCKENNA, F.; HARDY, G.E.St.J. Biological control of Sclerotinia minor using a chitinolytic bacterium and actinomycetes. Plant Pathology, v.49, p.573-583, 2000.

FERREIRA, D.F. Análises estatísticas por meio do Sisvar para Windows versão 4.0. In: REUNIÃO ANUAL DA REGIÃO BRASILEIRA DA SOCIEDADE INTERNACIONAL DE BIOMETRIA, 45., São Carlos, 2000. Programa e resumos. São Carlos: UFSCar, 2000a. p.255-258.

GETHA, K.; VIKINESWARY, S.; WONG, W.H.; SEKI, T.; WARD, A.; GOODFELLOW, M. Evaluation of Streptomyces sp. strain g10 for suppression of Fusarium wilt and rhizosphere colonization in pot-grown banana plantlets. Journal of Indian Microbiology and Biotechnology, v.32, p.24-32, 2005.
HIRSCH, C.F.; ENSIGN, J.C. Nutritionally defined conditions for germination of Streptomyces viridochromogenes spores. Journal of Bacteriology, v.126, p.13-23, 1976.

JENKINS, N.E.; HEVIEFO, G.; LANGEWALD, J.; CHERRY, A.J.; LOMER, C. Development of mass production technology for aerial conidia for use as mycopesticides. Biocontrol News and Information, v.19, p.21N-31N, 1998.

LANCINI, G.; LORENZETTI, R. Biotechnology of antibiotics and other bioactive microbial metabolites. New York: Plenum Press, 1993. 235p.

LIMA, L.L. Seleção de actinomicetos para o controle biológico de Ralstonia solanacearum e promoção de crescimento de mudas de tomateiro. Cruz das Almas: UFBA/Escola de Agronomia, 2003. 70p. (Dissertação - Mestrado).

MINUTO, A.; SPADARO, D.; GARIBALDI, A.; GULLINO, M.L. Control of soilborne pathogens of tomato using a commercial formulation of Streptomyces griseoviridis and solarization. Crop Protection, v.25, p.468-475, 2006.

NELSON, T.L.; LOW, A.; GLARE, T.R. Large production of New Zealand strains of Beauveria and Metarhizium. In: NEW ZEALAND PLANT PROTECTION CONFERENCE, 49., Hamilton, 1996. Proceedings. Hastings: New Zealand Plant Protection Society, 1996. p.257-261.

NOLAN, R.D.; CROSS, T. Isolation and screening of actinomycetes. In: GOODFELLOW, M.; WILLIAMS, S.T.; MORDARSKI, M. (Ed.). Actinomycetes in biotechnology. Orlando: Academic Press, 1988.

POTER, J.N.; WILHELM, J.J.; TRESNER, H.D. Method for the preferential isolation of actinomycetes from soils. Applied Microbiology, v.8, p.174-178, 1960.

SOARES, A.C.F.; SOUSA, C.S.; GARRIDO, M.S.; PEREZ, J.O.; ALMEIDA, N.S. Soil streptomycetes with in vitro activity against the yam pathogens Curvularia eragostrides and Colletotrichum gloeosporioides. Brazilian Journal of Microbiology, v.37, p.456-461, 2006.

SOUSA, C.S. Estreptomicetos promotores de crescimento e agentes de biocontrole da meloidoginose no tomateiro. Cruz das Almas: UFBA/Escola de Agronomia, 2006. 102p. (Dissertação Mestrado).

SOUSA, C.S.; SOARES, A.C.F.; GARRIDO, M.S.; ALMEIDA, G.M.C.O. Estreptomicetos no controle da meloidoginose em mudas de tomateiro. Pesquisa Agropecuária Brasileira, v.41, p.1759-1766, 2006.

STEVENSON, I.L. Antibiotic activity of actinomycetes in soil and their controlling effects on root-rot of Wheat. Journal of General Microbiology, v.14, p.440-448, 1956.

Received January 20, 2006

Accepted August 14, 2007 